\title{
Effect of Nonylphenol on Plasma Vitellogenin of Male Adult Guppies (Poecilia reticulata)
}

\author{
Mei-Hui Li, Zhen-Rui Wang \\ Environmental Toxicology Laboratory, Department of Geography, National Taiwan University, \\ Number 1, Section 4, Roosevelt Road, Taipei 106, Taiwan, Republic of China
}

Received 24 May 2004; revised 25 August 2004; accepted 6 September 2004

\begin{abstract}
Adult male guppies (Poecilia reticulata) were exposed to 4-nonylphenol (NP) at nominal concentrations of 10,60 , and $150 \mu \mathrm{g} / \mathrm{L}$ for 7,14 , or 21 days. Significant induction of vitellogenin (VTG) was found in male guppies exposed to $1 \mu \mathrm{g} / \mathrm{L}$ of $17 \beta$-estradiol and 60 or $150 \mu \mathrm{g} / \mathrm{L}$ of NP after 7,14 , or 21 days. Maximum induction was seen after 14 days of treatment at these concentrations. On the other hand, significant induction of VTG in male guppies exposed to $10 \mu \mathrm{g} / \mathrm{L}$ of NP was observed only after 21 days of treatment. A time-dependent tendency of reduction of the gonadosomatic index (GSI) in male guppies treated with $17 \beta$-estradiol or NP was observed, but no corresponding concentration-dependent tendency was detected. There were also no differences in the liver somatic index (LSI) of male fish treated with various concentrations of NP during the above-mentioned exposure periods. Preliminary data presented in this study strongly suggests that measurement of plasma VTG induction in male guppies is a suitable and rather sensitive indicator of exposure to estrogenic chemicals. (c) 2005 Wiley Periodicals, Inc. Environ Toxicol 20: 53-59, 2005.
\end{abstract}

Keywords: guppy; Poecilia reticulata; nonylphenol; vitellogenin; endocrine disruption; biological indicator; gonadosomatic index

\section{INTRODUCTION}

There is increasing concern about the potential risk in wildlife and humans of exposure to man-made chemicals possessing endocrine-disrupting ability (Colborn et al., 1993). Among aquatic animals, fish are especially prone to exposure to endocrine disruptors in their ambient environment, and those in the wild can exhibit a variety of reproductive problems including masculinization of females (Cody et al., 1997), feminization of males (Jobling et al., 1998), altered sex hormone levels and gonadal abnormali-

Correspondence to: M.-H. Li; e-mail: meihuili@ntu.edu.tw

Contract grant sponsor: National Science Council.

Contract grant number: NSC91-2313-B-002-395.

Published online in Wiley InterScience (www.interscience.wiley.com). DOI 10.1002/tox.20077 ties (Hashimoto et al., 2000), and reduced fertility (Jobling et al., 2002). Therefore, fish can be used as experimental models in studies of endocrine disruption effects and also can serve as an early-warning indicator of effects that may later become apparent in other wildlife species and in humans.

Before predicting the possible effects of endocrine disruptors in wildlife, it is important to assess the exposure status of endocrine disruptors in organisms in their environment. Induction of vitellogenin (VTG) in male fish has been widely used as an indicator of exposure to xenoestrogens both in field and in laboratory conditions. VTG is a yolk precursor protein produced in the liver under the stimulation of ovarian estradiol and is normally found in the blood of female fish, whereas plasma VTG levels in male fish are normally very low or not present (Kime et al., 1999). However, VTG synthesis and release can be induced in the 
livers of male fish if exposed to exogenous estrogen (Kime et al., 1999). The presence of plasma VTG in male fish therefore is considered a sensitive biomarker of exposure to both estrogens and xenoestrogens (Sumpter and Jobling, 1995).

The guppy, which is very well adapted to the streams of Southeast Asia (Wildianarko et al., 2000), is a viviparous tropical fish with a short life cycle. It is widely used as a test organism in investigations of aquatic toxicity because it is a readily available and easily handled species. This fish model offers several reproductive endpoints for assessing the cellular, behavioral, morphological, histological, and population-level effects of endocrine disruptors (Bayley et al., 1999, 2002; Haubruge et al., 2000; Baatrup and Junge, 2001; Toft and Baatrup, 2001, 2003; Larsson et al., 2002; Kinnberg and Toft, 2003; Kinnberg et al., 2003). However, only limited information is available on the VTG production of this species in response to exposure to xenoestrogens (Wester et al., 1985).

The objective of this study was to investigate the effects of 4-nonylphenol (NP) on VTG induction in male adult guppies. NP was selected as a testing chemical because of its industrial, commercial, and household applications all over the world (Bennie, 1999). This compound was detected in surface water and sediment in the rivers of Taiwan (Ding et al., 1999; Wang et al., 2001), and was found to be estrogenic both in vivo and in vitro (Nimrod and Benson, 1996). In this study we have demonstrated a dose-response relationship of plasma VTG induction in male guppies in response to NP during three different exposure periods.

\section{MATERIALS AND METHODS}

\section{Chemicals and Reagents}

4-Nonylphenol was obtained from Fluka (Switzerland). Trizma base, ethylenediamine tetraacetic acid (EDTA), and glycerol were purchased from J.T. Baker (Phillipsburg, NJ, USA). Acetone, 17 $\beta$-estradiol, MS222, aprotinin, heparin, and all other chemicals used in electrophoresis were obtained from Sigma Chemical Company (Saint Louis, MO, USA).

\section{Animals and Experimental Design}

Adult male guppies were obtained from a local supplier and acclimated in the laboratory to a temperature of $24^{\circ} \mathrm{C} \pm 1{ }^{\circ} \mathrm{C}$ and a 12-h photoperiod for at least 7 days prior to the experiments. The guppies were fed daily with commercial dry flake food (AZOO 9 in 1 guppy pellet, AZOO Company, Taiwan). To eliminate the risk of leached potential endocrine disruptors, plastic materials were avoided in all aquariums and plumbing. Dechlorinated tap water was stored in a stainless-steel tank before use. The fish were exposed to either NP at nominal concentrations of 10,60 , and $150 \mu \mathrm{g} / \mathrm{L}, 17 \beta$-estradiol at a nominal concentration of $1 \mu \mathrm{g} / \mathrm{L}$ as a positive control, or acetone alone at a nominal concentration of $30 \mathrm{ppm}$ as a solvent control. The test chemicals were dissolved in acetone, and the test water was replaced three times a week in all beakers in order to maintain treatment concentrations. Each group of six male guppies was kept in $5 \mathrm{~L}$ of water in a glass beaker at the beginning of each treatment, and half of the guppies were removed from each beaker after different exposure periods (7 or 14 days; 14 or 21 days; 7 or 21 days). There were 21 guppies in each treatment group at the beginning of exposure. The fish were inspected daily for mortality during the entire experimental period.

\section{Tissue Preparation}

After 7, 14, or 21 days of exposure, all fish were exposed to water containing heparin $(2000 \mathrm{U} / \mathrm{L})$ for $30 \mathrm{~min}$ and then were anesthetized in MS222 $(300 \mu \mathrm{g} / \mathrm{L})$ for $15 \mathrm{~min}$. Blood samples were collected by cardiac puncture into a microsyringe and transferred to plastic Eppendorf tubes containing aprotinin. Because the fish were small in size, blood from two or three guppies was contributed to make up one blood sample in this study. Blood samples were centrifuged at $10000 \times \mathrm{g}$ for $10 \mathrm{~min}$, and the resulting plasma volume of each sample was measured with a $10-\mu \mathrm{L}$ Hamilton syringe. The resulting plasma was then stored at liquid nitrogen until analyzed. Whole-body, liver, and testis wet weights of each guppy also were measured. The gonadosomatic index (GSI) was calculated as the percentage of the testis weight to the whole-body weight. The liver somatic index (LSI) was calculated as the percentage of the liver weight to the whole-body weight.

\section{Vitellogenin Determination}

Semiquantification of plasma VTG concentration was carried out by gel electrophoresis followed by densitometric analysis of the VTG band as described by Janssen et al. (1997). In brief, plasma samples [0.05 M Tris (pH 6.8), $2.15 \mathrm{mM}$ EDTA, 1\% SDS, $1 \% \beta$-mercaptoethanol] were combined with an equal volume of native sample buffer (8\% glycerol, $0.025 \%$ bromophenol blue) and placed into nearly boiling water $\left(95^{\circ} \mathrm{C}\right)$ for $10 \mathrm{~min}$ to denature the proteins. Then plasma samples were analyzed by reducing sodium dodecylsulfate-polyacrylamide gel electrophoresis (SDS-PAGE) using a 4\% stacking gel and a 7.5\% running gel of polyacrylamide. The gels were run in a Hoefer Might Samll II SE250 Mini-Vertical Electrophoresis Unit (Amersham Pharmacia Biotech, Piscataway, NJ, USA) with a constant current of $40 \mathrm{~V}$ for $30 \mathrm{~min}$ and $120 \mathrm{~V}$ for another $60 \mathrm{~min}$ at room temperature. Gels were stained with $0.02 \%$ Coomassie blue R-250 for 15 min to indicate protein bands 


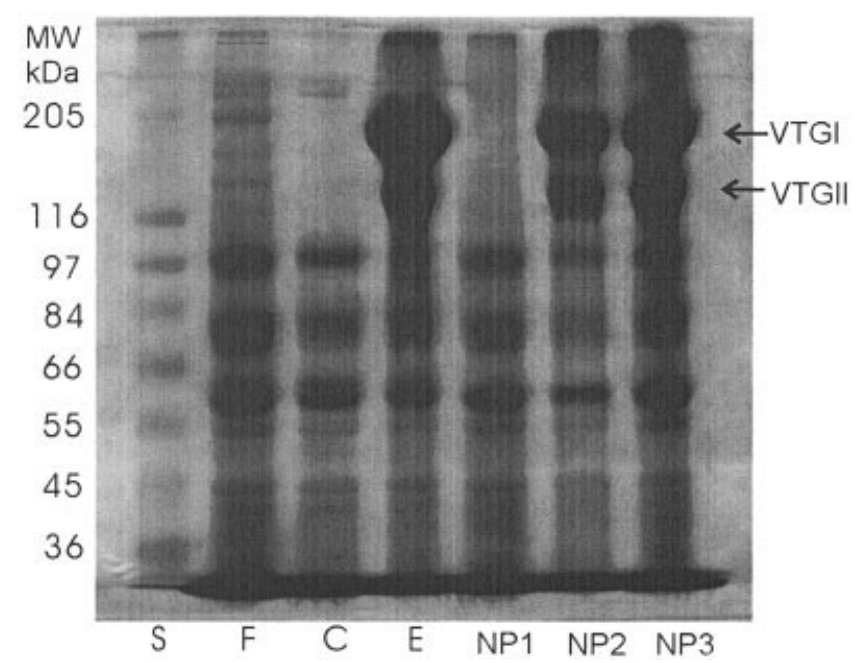

Fig. 1. SDS-PAGE gel from guppy plasma samples treated with NP or $17 \beta$-estradiol after 14 days of treatment. Lane 1 $(\mathrm{S})$, molecular weight protein standards; lane $2(\mathrm{~F})$, reference female; lane $3(\mathrm{C})$, control male; lane 4 (E), $1 \mu \mathrm{g} / \mathrm{L} 17 \beta$ estradiol-treated male; lane 5 (NP1), $10 \mu \mathrm{g} / \mathrm{L}$ NP-treated male; lane 6 (NP2), $60 \mu \mathrm{g} / \mathrm{L}$ NP-treated male; lane 7 (NP3), $150 \mu \mathrm{g} / \mathrm{L}$ NP-treated male.

and destained first with $25 \%$ methanol and $10 \%$ acetic acid, followed by $5 \%$ methanol and $7 \%$ acetic acid overnight. The resulting gels were digitized and then analyzed using Imagequant 5.0 (Molecular Dynamics, Sunnyvale, CA, USA). A reference sample from the aliquots of the pooled plasma collected from 36 adult female guppies was also analyzed in each gel. Therefore, the relative amount of VTG protein from different treatment groups could be calculated against this reference sample in each gel.

\section{Statistical Analyses}

All data were expressed as the mean \pm standard deviation (SD). Differences among the treatment groups were analyzed with the nonparametric Kruskal-Wallis test using the Minitab statistical program (Version 13.2). If a significant result were found, the Mann-Whitney $U$ test was used to determine which treatment groups were significantly different from the controls. Differences were considered significant at $P \leq 0.05$.

\section{RESULTS}

\section{Identification of VTG}

Two protein bands were detected in the plasma samples from adult female and 17-estradiol-treated male guppies but not from normal adult male guppies (Fig. 1).

These two bands (VTG I and VTG II) were tentatively identified as guppy vitellogenin in our SDS-PAGE gels. The molecular weights for VTG I and VTG II were estimated to be 191 and $156 \mathrm{kDa}$, respectively. Only VTG I protein appeared to be highly expressed and was used to quantify VTG induction in male guppies in the present study.

\section{Dose- and Time-Dependence of NP-induced VTG}

NP induced dose-dependent production of VTG in male guppies at different exposure periods. Densitometric analysis indicated that the level of VTG in male fish was about $82 \%-89 \%$ of that in female fish at $10 \mu \mathrm{g} / \mathrm{L}$ of NP during three different exposure periods (Fig. 2). There were about 2-, 4-, and 14-fold increases in VTG levels in male guppies exposed to $10 \mu \mathrm{g} / \mathrm{L}$ of NP compared to control male guppies for 7, 14, and 21 days of treatment, respectively; however, significant induction of VTG in male guppies was only observed after a 21 -day exposure $(P=0.0307)$. On the other hand, significant induction of VTG was found in male guppies exposed to $1 \mu \mathrm{g} / \mathrm{L}$ of $17 \beta$-estradiol, 60 and $150 \mu \mathrm{g} / \mathrm{L}$ of NP after all three periods of treatment (Fig. 2). NP-induced (60 and $150 \mu \mathrm{g} / \mathrm{L}$ ) and $17 \beta$-estradiol-induced (1 $\mu \mathrm{g} / \mathrm{L})$ VTG levels in male guppies were already at their maximum after 14 days of treatment and remained at a similar level of VTG induction after 21 days of treatment (Fig. 2).

\section{Effect of NP on GSI and LSI in Male Guppies}

There were no differences in body weight among the treatment groups (data not shown). Clear dose- or time-related mortality was not observed in our treatment groups. The

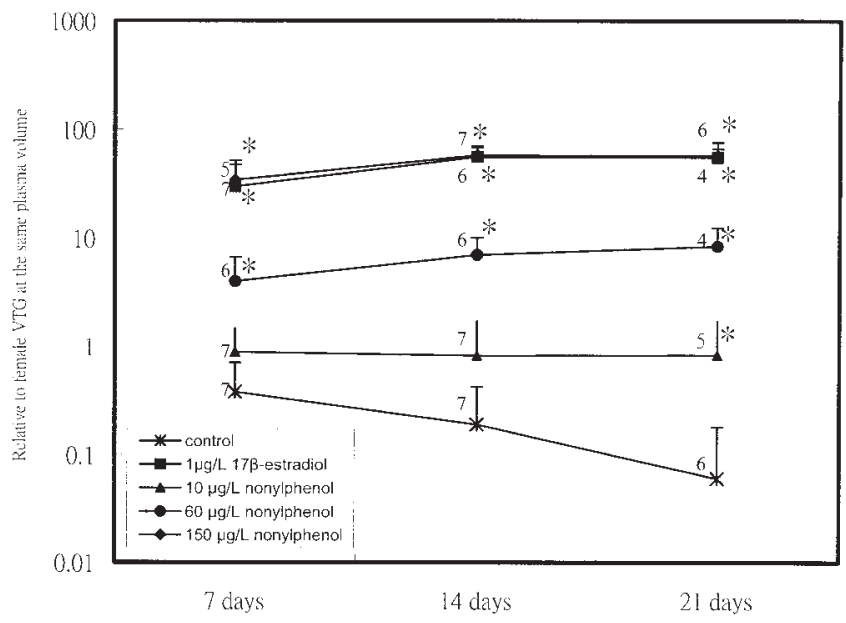

Fig. 2. Relative plasma vitellogenin (mean \pm SD) in male guppies relative to that in reference female plasma samples after 7,14 , and 21 days of exposure to NP or $17 \beta$-estradiol, respectively. Numbers next to means indicate number of composite plasma samples per respective treatment. An asterisk denotes a significant difference from the respective controls at $P<0.05$. 


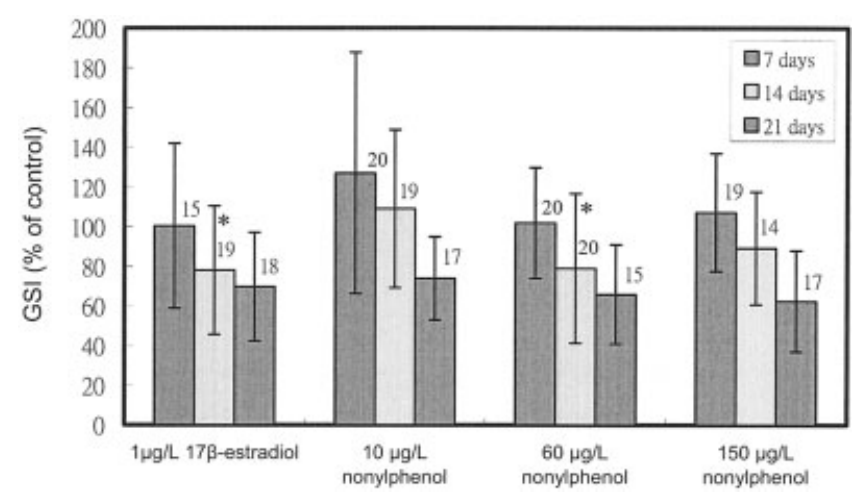

Fig. 3. Effects of $17 \beta$-estradiol and NP on the GSI (mean \pm $\mathrm{SD}$ ) in male guppies after 7, 14, or 21 days of treatment. Numbers next to means indicate number of fish per respective treatment. An asterisk denotes a significant difference from the controls with the same exposure time at $P<0.05$.

percentage of survival in most treatment groups was above $80 \%$, except for the fish exposed to $1 \mu \mathrm{g} / \mathrm{L}$ of $17 \beta$-estradiol for 7 days $(71 \%), 150 \mu \mathrm{g} / \mathrm{L}$ of NP for 14 days $(67 \%)$, and $60 \mu \mathrm{g} / \mathrm{L}$ of NP for 21 days (71\%). Although a time-related tendency toward a reduction of the GSI in male guppies treated with $17 \beta$-estradiol or NP was shown, the GSI in guppies treated with $1 \mu \mathrm{g} / \mathrm{L}$ of $17 \beta$-estradiol or $60 \mu \mathrm{g} / \mathrm{L}$ of NP after a 14-day exposure decreased significantly (Fig. 3). A plot of the GSI as a function of plasma VTG showed a significant negative correlation $(r=-0.522, P=0.046$; Fig. 4). In addition, there were no differences in the LSI of male fish treated with different concentrations of NP for different exposure times. The LSI of male guppies treated with $1 \mu \mathrm{g} / \mathrm{L}$ of $17 \beta$-estradiol was significantly higher than that of the control after 7 days of exposure but not significantly different than that of the control after 14 or 21 days of exposure (data not shown).

\section{DISCUSSION}

The purpose of this study was to examine the usefulness of plasma VTG production in male guppies as a biomarker to detect estrogenic exposure. Although Wester et al. (1985) reported that VTG production was found in juvenile male guppies exposed to $0.01 \mathrm{mg} / \mathrm{L}$ of $17 \beta$-estradiol or $1 \mathrm{mg} / \mathrm{L}$ of $\beta$-hexachlorocyclohexane after 2 weeks of treatment, a quantitative dose-response relationship of the VTG induction was lacking. In our study we measured plasma VTG induction in male guppies exposed to different concentrations of NP after 7, 14, or 21 days of treatment. Significant induction of VTG was found in male guppies exposed to $1 \mu \mathrm{g} / \mathrm{L}$ of $17 \beta$-estradiol, 60 and $150 \mu \mathrm{g} / \mathrm{L}$ of NP after 7, 14 , or 21 days of treatment, and VTG induction was already at its maximum after 14 days of treatment. This result is in good agreement with reports from similar studies that mentioned that plasma VTG induction of male fish was a sen- sitive indicator of estrogenic exposure (Mills et al., 2001; Pait and Nelson, 2003).

In our study gel electrophoresis showed two protein bands related to estrogen-induced proteins, presumably VTG, with estimated molecular weights of 191 and $156 \mathrm{kDa}$. This result is in agreement with those of other studies. Wester et al. (1985) identified increased VTG production in juvenile male guppies exposed to $1 \mathrm{mg} / \mathrm{L}$ of $\beta$-hexachlorocyclohexane after 2 weeks of treatment, with estimated molecular weights of 200 and $140 \mathrm{kDa}$. Van den Belt et al. (2003) reported two protein bands with molecular weights of 193 and $138 \mathrm{kDa}$ for zebrafish (Danio rerio) and 177 and $138 \mathrm{kDa}$ for juvenile rainbow trout (Oncorhynchus mykiss), using gel electrophoresis. Fukada et al. (2003) also found two protein bands with molecular weights of 190 and $156 \mathrm{kDa}$ after SDS-PAGE for carp (Cyprinus carpio). In their study further evidence was provided by the fact that these proteins were seen only in female fish and $17 \beta$ estradiol-treated males but not in normal male plasma. In the present study exposure of male guppies to NP resulted in the same protein bands as those exhibited in the plasma of female guppies and $17 \beta$-estradiol-treated males in a concentration-dependent manner.

Compared with the published data on the lowestobserved-effect concentration (LOEC) of plasma VTG induction in fish exposed to NP (Table I), the LOEC of NP $(60 \mu \mathrm{g} / \mathrm{L}$ of NP in a 1-week exposure) found for male guppies in our study was at the lower end of the range (4-500 $\mu \mathrm{g} / \mathrm{L}$ of NP) reported for male fish. This further suggests that the measurement of plasma VTG induction in male guppies is a suitable and rather sensitive indicator of NP exposure. In our experimental conditions no further induction of VTG in male guppies occurred between 14 and 21 days of treatment. On the other hand, the significant

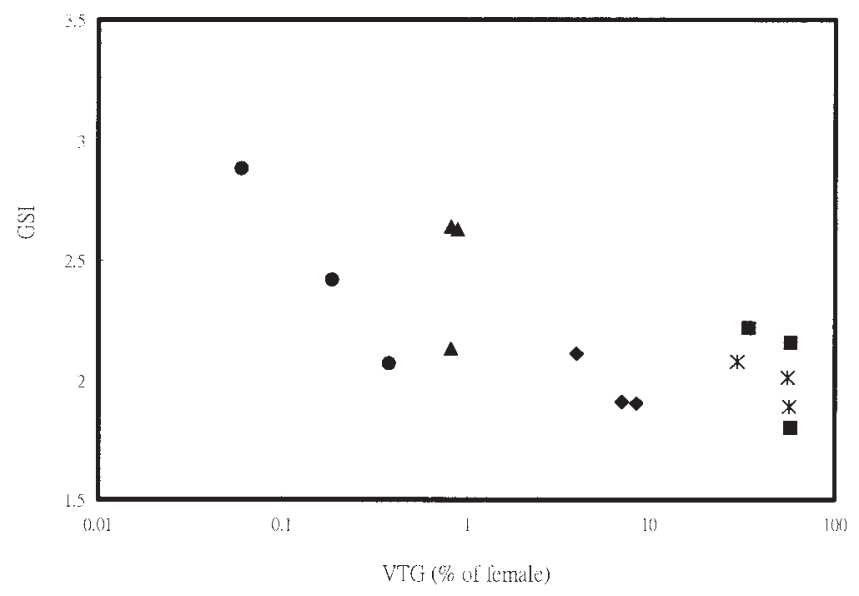

Fig. 4. Correlation $(r=-0.522, P=0.046)$ between plasma VTG induction and GSI in male guppies exposed to NP for 7, 14, or 21 days of treatment ( $\bullet$ : control; *: $1 \mu \mathrm{g} / \mathrm{L}$ of $17 \beta$-estradiol; $\mathbf{\Delta}$ : $10 \mu \mathrm{g} / \mathrm{L}$ of $\mathrm{NP} ; \diamond: 60 \mu \mathrm{g} / \mathrm{L}$ of $\mathrm{NP} ; \boldsymbol{\square}$ $150 \mu \mathrm{g} / \mathrm{L}$ of NP). 
TABLE I. Lowest observed effect concentration (LOEC) of plasma VTG induction in different fish exposed to waterborne NP

\begin{tabular}{|c|c|c|c|c|}
\hline Species & Status & $\begin{array}{c}\text { Exposure Type } \\
\text { (nominal concentration used) }\end{array}$ & LOEC VTG Induction & Reference \\
\hline \multirow{3}{*}{$\begin{array}{l}\text { Rainbow trout } \\
\text { (Oncorhynchus } \\
\text { mykiss) }\end{array}$} & male & 3-week flow-through $(0.5-65 \mu \mathrm{g} / \mathrm{L})$ & $24.5 \mu \mathrm{g} / \mathrm{L}(20.3 \mu \mathrm{g} / \mathrm{L})^{\mathrm{a}}$ & Jobling et al., 1996 \\
\hline & juvenile male & 3-week semistatic $(20-500 \mu \mathrm{g} / \mathrm{L})$ & $100 \mu \mathrm{g} / \mathrm{L}$ & Van den Belt et al., 2003 \\
\hline & juvenile male & 3-week semistatic $(25-100 \mu \mathrm{g} / \mathrm{L})$ & $50 \mu \mathrm{g} / \mathrm{L}$ & $\begin{array}{l}\text { Tremblay and Kraak, } \\
1998\end{array}$ \\
\hline $\begin{array}{l}\text { Sheephead minnow } \\
\text { (Cyrinodon } \\
\text { variegates) }\end{array}$ & male & 3-week flow-through, $(1-80 \mu \mathrm{g} / \mathrm{L})$ & $10 \mu \mathrm{g} / \mathrm{L}(5.4 \mu \mathrm{g} / \mathrm{L})^{\mathrm{a}}$ & Hemmer et al., 2001 \\
\hline \multirow[t]{2}{*}{ Carp (Cyprinus carpio) } & male & $\begin{array}{l}28 \text { to } 31 \text { day flow-through, }(0.1- \\
10 \mu \mathrm{g} / \mathrm{L})\end{array}$ & no induction observed & Villeneuve et al., 2002 \\
\hline & juvenile male & $\begin{array}{l}42 \text { days (exposure condition } \\
\text { unknown) }(4-256 \mu \mathrm{g} / \mathrm{L})\end{array}$ & $4 \mathrm{ug} / \mathrm{L}$ & Huang and Wang, 2001 \\
\hline \multirow{2}{*}{$\begin{array}{l}\text { Japanese medaka } \\
\text { (Oryzias latipes) }\end{array}$} & male & 1-day semistatic $(20 \mu \mathrm{g} / \mathrm{L})$ & $20 \mu \mathrm{g} / \mathrm{L}$ & Foran et al., 2000 \\
\hline & male & 4-day semistatic $(20 \mu \mathrm{g} / \mathrm{L})$ & $20 \mu \mathrm{g} / \mathrm{L}$ & Foran et al., 2000 \\
\hline \multirow[t]{2}{*}{ Zebrafish (Danio rerio) } & male & 3-week semistatic $(20-500 \mu \mathrm{g} / \mathrm{L})$ & $500 \mu \mathrm{g} / \mathrm{L}$ & Van den Belt et al., 2003 \\
\hline & young male & $\begin{array}{l}\text { from } 2 \text { to } 60 \text { days posthatch } \\
\text { semistatic }(10-100 \mu \mathrm{g} / \mathrm{L})\end{array}$ & $30 \mu \mathrm{g} / \mathrm{L}$ & Hill and Janz, 2003 \\
\hline $\begin{array}{l}\text { Goldfish (Carassius } \\
\text { auratus) }\end{array}$ & male & 5-day static $(500 \mu \mathrm{g} / \mathrm{L})$ & $500 \mu \mathrm{g} / \mathrm{L}$ & Kitamura et al., 1999 \\
\hline $\begin{array}{l}\text { Platyfish (Xiphophorus } \\
\text { maculates) }\end{array}$ & male & 4-week semistatic $(80-1280 \mu \mathrm{g} / \mathrm{L})$ & $80 \mu \mathrm{g} / \mathrm{L}$ & Kinnberg et al., 2000 \\
\hline \multirow{2}{*}{$\begin{array}{l}\text { Guppy (Poecilia } \\
\text { reticulata) }\end{array}$} & male & 1-week semistatic $(10-150 \mu \mathrm{g} / \mathrm{L})$ & $60 \mu \mathrm{g} / \mathrm{L}$ & This study \\
\hline & male & 3-week semistatic $(10-150 \mu \mathrm{g} / \mathrm{L})$ & $10 \mu \mathrm{g} / \mathrm{L}$ & This study \\
\hline
\end{tabular}

${ }^{a}$ Measured actual NP water concentration.

induction of VTG in male guppies treated with $10 \mu \mathrm{g} / \mathrm{L}$ of NP compared to that in the controls after 21 days of exposure should be interpreted with caution. This might have occurred as a result of a reduced background level of VTG of the corresponding control fish, as the relative VTG levels in male guppies treated with $10 \mu \mathrm{g} / \mathrm{L}$ of NP remained almost the same $(82 \%-89 \%$ of reference female VTG levels) across three exposure durations (Fig. 2). According to our results, a 7-day exposure is sufficient to detect $60 \mu \mathrm{g} / \mathrm{L}$ of NP-induced VTG production in male guppies.

Freshwater concentrations of NP have been reported in the range of $<0.01-180 \mu \mathrm{g} / \mathrm{L}$, and the average concentration of NP is usually less than $10 \mu \mathrm{g} / \mathrm{L}$ (Bennie, 1999). A study of 40 rivers in Taiwan revealed an average NP concentration of $4.87 \mu \mathrm{g} / \mathrm{L}$, with a range of $0.89-50 \mu \mathrm{g} / \mathrm{L}$ (Wang et al., 2001). The actual NP concentrations in test water have been reported as approximately .33-.50 and $.17-.25$ of the nominal concentration after 48 and $72 \mathrm{~h}$, respectively (Gray and Metcalfe, 1997; Kinnberg et al., 2000). The actual NP concentrations tested in the present study were roughly estimated, by changing the water 3 times a week, as .25-.33 of the nominal concentrations based on our experimental scheme. Therefore, male guppies exposed to 10,60 , and $150 \mu \mathrm{g} / \mathrm{L}$ of NP in the present study can be considered exposed to NP at environmentally relevant concentrations. It further suggests the usefulness of this fish model for detecting potential exposure to xenoestrogens in environmental samples.

A decreased GSI can be used as an indicator of gonadal dysfunction resulting from decreased hypothalamic, pituitary, or gonadal activity (Kime, 1999). In fact, decreased GSI was commonly observed, although less pronounced, after estrogenic exposure in fish (Jobling et al., 1996; Christiansen et al., 1998a; Kinnberg et al., 2000; Mills et al., 2001). In our study VTG induction was significantly correlated with a reduced GSI in male guppies. We observed an exposure-related decrease of the GSI in male guppies at each NP concentration, but a dose-related decrease of the GSI was less obvious for each exposure duration (Fig. 3). That there was not a strong concentration-related tendency of the GSI in guppies in the present study might be a result of the narrow NP concentration range used.

In general, an increased LSI is expected from VTG induction resulting from enhanced liver metabolism, leading to an enlarged liver. However, according to published data, an increased LSI is not a good indicator of estrogenic 
exposure. For example, Christiansen et al. (1998a) found no significant difference in the LSI of male eelpout (Zoarces viviparous) treated with NP or $17 \beta$-estradiol after 25 days of injection. In a different study, these investigators (Christiansen et al., 1998b) reported a significant increase in the LSI of rainbow trout treated with diethylstilbestrol (DES), $17 \alpha$-ethinyl estradiol, and bisphenol A, but not in fish treated with $17 \beta$-estradiol, NP, butylbenzylphthalate, and dibutylphthalate. Juvenile male summer flounder (Paralichthys dentatus) treated with octylphenol also showed no change in the LSI, whereas $17 \beta$-estradiol-treated fish ( 2 and $20 \mathrm{mg} / \mathrm{kg}$ ) exhibited an increased LSI after 4 weeks of treatment (Mills et al., 2001). Interestingly, Verslycke et al. (2002) reported that no concentration-dependent changes in the LSI was observed in rainbow trout exposed to waterborne $17 \alpha$-ethinyl estradiol after 14 days of treatment, but a significant dose-dependent increase of the LSI was found in fish injected with $17 \alpha$-ethinyl estradiol. In our study we also observed no significant changes in the LSI of male guppies treated with NP or $17 \beta$-estradiol, except for a significant increase in the LSI of fish exposed to $1 \mu \mathrm{g} / \mathrm{L}$ of $17 \beta-$ estradiol after 7 days of treatment.

\section{CONCLUSIONS}

The results of this study demonstrated that NP and $17 \beta$ estradiol exert similar effects on induction of the GSI and of VTG in male guppies and also confirmed that NP is estrogenic in fish. Indeed, guppies can be considered a suitable and sensitive species for the measurement of plasma VTG for estrogenic exposure at environmentally relevant concentrations by using the semiquantitative SDS-PAGE method. Furthermore, it will be useful to develop guppies as an integrated fish model suitable not only for assessing the effects of xenoestrogens but also for detecting exposure to xenoestrogens.

\section{REFERENCES}

Baatrup E, Junge M. 2001. Antiandrogenic pesticides disrupt sexual characteristics in the adult male guppy (Poecilia reticulata). Environ Health Perspect 109:1063-1070.

Bayley M, Junge M, Baatrup E. 2002. Exposure of juvenile guppies to three antiandrogens causes demasculinization and a reduced sperm count in adult males. Aquat Toxicol 56:227-239.

Bayley M, Nielsen JR, Baatrup E. 1999. Guppy sexual behavior as an effect biomarker of estrogen mimics. Ecotoxicol Environ Saf 43:68-73.

Bennie DT. 1999. Review of the environmental occurrence of alkylphenols and alkylphenol ethoxylates. Water Qual Res J Canada 34:79-122.

Christiansen T, Korsgaard B, Jespersen A. 1998a. Effects of nonylphenol and $17 \beta$-estradiol on vitellogenin synthesis, testicular structure and cytology in male eelpout (Zoarces viviparous). J Exp Biol 201:179-192.

Christiansen LB, Pedersen KL, Korsgaard B, Bjerregaard P. 1998b. Estrogenicity of xenobiotics in rainbow trout (Oncorhynchus mykiss) using in vivo synthesis of vitellogenin as a biomarker. Mar Environ Res 46:137-140.

Cody RP, Ewing LL, Niswender GD. 1997. Masculinization of mosquitofish as an indicator of exposure to Kraft mill effluent. Bull Environ Contam Toxicol 58:429-436.

Colborn C, vom Saal FS, Soto AM. 1993. Developmental effects of endocrine-disrupting chemicals in wildlife and humans. Environ Health Perspect 101:378-384.

Ding WH, Tzing SH, Lo JH. 1999. Occurrence and concentrations of aromatic surfactants and their degradation products in river waters of Taiwan. Chemosphere 38:2569-2606.

Foran CM, Bennett ER, Benson WH. 2000. Exposure to environmentally relevant concentrations of different nonylphenol formulations in Japanese medaka. Mar Environ.Res 50:135-139.

Fukada H, Fujiwara Y, Takahashi T, Hiramatsu A, Sullivan CV, Hara A. 2003. Carp (Cyprinus carpio) vitellogenin: purification and development of a simultaneous chemiluminescent immunoassay. Comp Biochem Physiol A 134:615-623.

Gray MA, Metacalfe CD. 1997. Induction of testis-ova in Japanese medaka (Oryzias latipes) exposed to p-nonylphenol. Environ Toxicol Chem 16:1082-1086.

Hashimoto S, Bessho H, Hara A, Nakamura M, Iguchi T, Fujita K. 2000. Elevated serum vitellogenin levels and gonadal abnormalities in wild male flounder (Pleuronectes yokohamae) from Tokyo Bay, Japan. Mar Environ Res 49:37-53.

Haubruge E, Petit F, Cage MJG. 2000. Reduced sperms counts in guppies (Poecilia reticulata) following exposure to low levels of tributyltin and bisphenol A. Proc R Soc Lond B 267:23332337.

Hemmer MJ, Hemmer BL, Bowman CJ, Kroll KJ, Folmar LC, Marcovich D, Hoglund MD, Denslow ND. 2001. Effects of p-nonylphenol, methoxychlor, and endosulfan on vitellogenin induction and expression in sheephead minnow (Cyrinodon variegates). Environ Toxicol Chem 20:336-343.

Hill RL, Janz Jr DM. 2003. Developmental estrogenic exposure in zebrafish (Danio rerio): I. Effects on sex ratio and breeding success. Aquat Toxicol 63:417-429.

Huang RK, Wang CH. 2001. The effects of two alkylphenols on vitellogenin levels in male carp. Proc Nat Sci Counc ROC B 25:248-252

Janssen PAH, Lambert JGD, Vethaak AD, Goos HJT. 1997. Environmental pollution caused elevated concentrations of oestradiol and vitellogenin in the female flounder, Platichthys flesus (L.). Aquat Toxicol 39:195-214

Jobling A, Sheahan D, Osborne JA, Matthiessen P, Sumpter JP. 1996. Inhibition of testicular growth in rainbow trout (Oncorhynchus mykiss) exposed to estrogenic alkylphenolic chemicals. Environ Toxicol Chem 15:194-202.

Jobling S, Nolan M, Tyler CR, Brighty G., Sumpter JP. 1998. Widespread sexual disruption in wild fish. Environ Sci Technol 32:2498-2506

Jobling S, Coey S, Whitemore JG, Kine DE, Van Look KJW, McAllister BG., Beresford N, Henshaw AC, Brighty G, Tyler 
CR, Sumpter JP. 2002. Wild intersex roach (Rutilus rutilus) have reduced fertility. Biol Reprod 67:515-524.

Kime DE, Nash JP, Scott AP. 1999. Vitellogenesis as a biomarker of reproductive disruption by xenobiotics. Aquaculture 177: $345-352$.

Kinnberg K, Korsgaard B, Bjerregaard P, Jespersen A. 2000. Effects of nonylphenol and $17 \beta$-estradiol on vitellogenin synthesis and testis morphology in male platyfish Xiphopjorus maculates. J Exp Biol 203:171-181.

Kinnberg K, Toft G. 2003. Effects of estrogenic and antiandrogenic compounds on the testis structure of the adult guppy (Poecilia reticulata). Ecotoxicol Environ Saf 54:16-24.

Kinnberg K, Korsgaard B, Bjerregaard P. 2003. Effects of octylphenol and $17 \beta$-estradiol on the gonads of guppies (Poecilia reticulata) exposed as adults via the water or as embryos via the mother. Comp Biochem Physiol C 134:45-55.

Kitamura S, Yoshida M, Sugihara K, Ohta S, Hara A. 1999. Effects of fenthion on the level of vitellogenin in goldfish, Carassius auratus. J Health Sci 45:262-265.

Larsson DGJ, Kinnberg K, Sturve J, Stephensen E, Skon M, Forlin L. 2002. Studies of masculinization, detoxification, and oxidative stress responses in guppies (Poecilia reticulata) exposed to effluent from a pulp mill. Ecotoxicol Environ Saf 52:13-20.

Mills LJ, Gutjahr-Gobell RE, Haebler RA, Horowitz DJB, Jayaraman S, Pruell RJ, McKinney RA, Gardner GR, Zaroogian GE. 2001. Effects of estrogenic (o, $p^{\prime}$-DDT; octylphenol) and antiandrogenic $\left(p, p^{\prime}\right.$-DDE) chemicals on indicators of endocrine status in juvenile male summer flounder (Paralichthys dentatus). Aquat Toxicol 52:157-176.

Nimrod AC, Benson WH. 1996. Environmental estrogenic effects of alkyphenol ethoxylates. Cri Rev Toxicol 26:335-364.

Pait AS, Nelson JO. 2003. Vitellogeneis in male Fundulus heteroclitus (killifish) induced by selected estrogenic compounds. Aquat Toxicol 64:331-342.

Sumpter JP, Jobling S. 1995. Vitellogenesis as a biomarker for oestrogenic contamination of the aquatic environment. Environ Health Perspect 103S:173-178.
Toft G, Baatrup E. 2001. Sexual characteristics are altered by 4-tert-octylphenol and 17b-estradiol in the adult male guppy (Poecilia reticulata). Ecotoxicol Environ Saf 48:76-84.

Toft G, Baatrup E. 2003. Altered sexual characteristics in guppies (Poecilia reticulata) exposed to $17 \beta$-estradiol and 4-tert-octylphenol during sexual development. Ecotoxicol Environ Saf 56: $228-237$.

Tremblay L, Van der Kraak G. 1998. Use of a series of homologus in vitro and in vivo assays to evaluate the endocrine modulating actions of $\beta$-sitosterol in rainbow trout. Aquat Toxicol 43:149162.

Van den Belt K, Verheyen R, Witters H. 2003. Comparison of vitellogenin responses in zebrafish and rainbow trout following exposure to environmental estrogens. Ecotoxicol Environ Saf $56: 271-281$

Verslycke T, Vandenbergh GF, Versonnen B, Arijs K, Janssen CR. 2002. Induction of vitellogenesis in $17 \alpha$-ethylestradiol-exposed rainbow trout (Oncorhynchus mykiss): a method comparison. Comp Biochem Physiol 132:483-492.

Villeneuve DL, Villalobos SA, Keith TL, Snyder EM, Fitzgerald SD, Giesy JP. 2002. Effects of waterborne exposure to 4-nonylphenol on plasma sex steroid and vitellogenin concentrations in sexually mature male carp (Cyprinus carpio). Chemosphere $47: 15-28$

Wang CH, Chang SP, Huang RK, Lee YH, Wang SK, Hung WT, Chen PS. 2001. Residues survey of nonylphenol and its biological effect on male carp. Taiwan J Public Health 20:202-215 (in Chinese with English abstract).

Wester PW, Canton JH, Bisschop A. 1985. Histopathological study of Poecilia reticulata (guppy) after long-term $\beta$-hexachlorocyclohexane exposure. Aquat Toxicol 6:271-296.

Widianarko B, Van Gestel CAM, Verweij RA, Van Straalen NM. 2000. Associations between trace metals in sediment, water, and guppy, Poecilia reticulata (Peters), from urban streams of Semarang, Indonesia. Ecotoxicol Environ Saf 46:101-107. 